\title{
Kerjasama Maritim Indonesia-Amerika Serikat sebagai Implementasi Politik Poros Maritim Indonesia: BAKAMLA-US Coast Guard
}

\author{
Muhammad Ridha Iswardhana \\ Hubungan Internasional Univeritas Teknologi Yogyakarta \\ Email: muhammad.ridha@staff.uty.ac.id
}

\begin{abstract}
Abstrak
Permasalahan maritim dan sengketa wilayah telah menjadi salah satu perhatian utama dunia, seiring dengan adanya kesadaran pentingnya laut dan berkembangnya permasalahan wilayah yang dipersengketakan antar negara terkait maritim. Berkaca pada adanya banyak berbagai kasus kejahatan di lautan serta kecelakaan yang menimbulkan banyak korban jiwa tentunya menjadi perhatian pentingnya keamanan laut. Penelitian ini dipilih mengingat lautan juga penting untuk dijaga dan diperhatikan, karena selama ini Indonesia lebih menitikberatkan pada pembangunan dan pengamanan di daratan. Penulis akan menggunakan metodologi kualitatif deskriptif dengan konsep Keamanan Maritim dan Kepentingan Nasional. Penelitian ini menemukan bahwa kerjasama antara Pemerintah Indonesia dan Pemerintah Amerika Serikat melalui lembaga Badan Keamanan Laut Indonesia (BAKAMLA RI) dan US Coast Guad merupakan salah satu wujud nyata mewujudkan Poros Maritim Dunia melalui keamanan dan penanggulangan bencana di laut. Terdapat berbagai kepentingan nasional Indonesia yang diuntungkan dengan adanya kerjasama ini, diantaranya transfer pengetahuan dan teknologi, kerjasama penanganan pencurian ikan dan kejahatan laut.
\end{abstract}

Kata kunci: Maritim, Keamanan Laut, Poros Maritim Dunia, BAKAMLA RI, US. Coast Guard.

\begin{abstract}
Maritime and territorial disputes have become one of the world's main concerns, along with the awareness of the importance of the sea and the development of disputed regional issues between countries related to maritime. Reflecting on the various crime cases in the sea also accidents that caused many casualties, are certainly big concern for the importance of sea security. This research was chosen considering that the ocean is also important to be maintained, because Indonesia has focused more on development and security on land than sea. The author will use descriptive qualitative methodology wih the concept of National Interest and Maritime Security. This study found that the collaboration between the Indonesian Goverment Indonesia and the Government of the United States through Indonesian Marine Security Agency (BAKAMLA RI) and the US Coast Guad is one tangible manifestation of realizing the World Maritime Axis through security and disaster management at sea. There are various Indonesian national interests that benefit from this collaboration, including transfer of knowledge and technology, cooperation in handling illegall fishing and marine crime.
\end{abstract}

Keywords: Maritime, Maritime Security, World Maritime Axis, BAKAMLA RI, US. Coast Guard. 


\section{PENDAHULUAN}

\section{Keamanan Laut Indonesia}

Posisi geografis Indonesia yang berada diantara dua benua maupun dua samudera, yakni: berada diantara Benua Asia dan Benua Australia maupun diantara Samudera Hindia dan Samudera Pasifik tentunya memiliki banyak kelebihan dan kekurangan. Lebih lanjut, realitas Indonesia sebagai negara kepulauan yang memiliki 17.504 pulau dengan sekitar $70 \%$ wilayah diantaranya merupakan lautan memerlukan adanya perhatian yang besar bagi pemerintah. Selain itu, Indonesia juga memiliki perbatasan langsung yang sebagian besar di lautan dengan berbagai negara, diantaranya Singapura, Malaysia, India, Filipina, Brunei Darussalam, Thailand, Vietnam, Palau, Timor Leste, hingga Australia. Berbagai kenyataan tersebut membuktikan bahwa Indonesia yang dikelilingi oleh lautan dan memiliki perbatasan langsung dengan banyak negara, tentunya memerlukan adanya perhatian untuk menjaga dan melindunginya.

Sering terdengar adanya kasus-kasus perompakan kapal oleh bajak laut yang mengincar kapal-kapal dagang yang mengangkut komoditas dengan harga tinggi, misalnya kapal tanker berisi minyak dan kelapa sawit. Tercatat pada medio Januari hingga Juni 2017, telah terjadi 87 kasus yang terjadi Indonesia (Berita Trans 2017). Meskipun dibandingkan tahun 2016 sebelumnya mengalami penurunan, namun angka tersebut masih besar dan menimbulkan keresahan dan mengancam keamanan laut Indonesia. Hal ini mengingat apabila terjadi pembajakan laut, tidak hanya kapal dan komoditas yang dibawa yang mengalami kerugian, melainkan juga awak kapal dan penumpangnya dapat mengalami luka-luka hingga menjadi korban penculikan, bahkan 4 kasus dai 87 kasus di atas tersebut dua orang terbunuh. Hal ini tentunya memerlukan adanya peningkatan keamanan laut di Indonesia, mengingat akan banyak kapal yang lalu lalang melewati laut Indonesia, baik kapal domestik maupun Internasional yang tentunya memerlukan adanya rasa aman dan memiliki kebebasan melintas guna mendukung berputarnya perekonomian Indonesia.

Meskipun sudah terdapat adanya Tentara Nasional Indonesia Angkatan Laut (TNI AL) yang berjaga dan mengamankan garis terdepan dari wilayah kedaulatan laut Indonesia, akan tetapi diperlukan adanya penguatan keamanan laut karena sejatinya TNI AL lebih cenderung menangani tentang pertahanan negara, sehingga diperlukan adanya lembaga yang dapat menangani terkait permasalahan keamanan laut. Di samping adanya perbedaan Tugas Pokok dan Fungsi (Tupoksi) dari TNI AL yang berbeda, tentunya juga proporsi jumlah kapal yang dimiliki oleh TNI AL cenderung masih terbatas dibandingkan luas lautan yang dimiliki oleh Indonesia. Kedua hal inilah yang memerlukan adanya pemecahan masalah segera agar tidak adanya insiden pembajakan kapan dan menimbulkan korban jiwa.

\section{Gelombang Pengungsi}

Pasca terjadinya konflik dan perang di berbagai negara Asia, seperti diantaranya Afganistan, Myanmar, Sri Lanka, Iran, Irak, dan Bangladesh 
menyebabkan terjadinya gelombang pengungsi yang besar meninggalkan negara mereka masing-masing menuju negara lain yang dianggap lebih aman dan memiliki masa depan. Akibatnya, adanya banyak pengungsi yang menggunakan kapal menuju ke Australia karena menganggap Australia dapat menerima mereka sebagai pencari suaka. Laut dipilih karena dapat mempersingkat jarak tempuh dan relatif lebih mudah dibandingkan menggunakan darat atau udara yang memerlukan adanya pemeriksaan dan persyaratan administratif.

Akan tetapi, lautan ternyata juga lebih berbahaya karena di laut terdapat ombak tinggi dan badai yang dapat datang tiba-tiba kapan pun, dapat menyebabkan kapal terbalik dan hanyut hingga menimbulkan banyak korban jiwa. Selain itu, kurangnya pengetahuan dan pengalaman tentang laut juga dapat mengancam keselamatan, misalnya sebuah kapal kecil dipaksa dijejali dengan banyak penumpang yang melebihi kapasitas, tidak membawa perbekalan yang cukup, hingga bahan bakar yang minim dapat menimbulkan adanya konflik dan membahayakan keselamatan dari para penumpang tersebut. Apalagi jika para pemilik kapal tersebut ternyata para sindikat penyelundup dan pelaku kejahatan yang tentu saja hanya mengincar uang dari para pengungsi, tanpa memperhatikan adanya keselamatan dan keamanan dari penumpangnya. Tidak jarang kemudian mereka membiarkan begitu saja para pengungsi terombang-ambing di tengah lautan tanpa kejelasan. Lebih lanjut, mereka semua tentunya tidak memiliki dokumen yang jelas dan izin ketika meninggalkan negara asal maupun akan memasuki negara tujuan, sehingga mereka masuk dalam katagori imigran ilegal yang dapat ditangkap kapan saja oleh para pihak berwenang di berbagai negara ketika menuju Australia.

Hal yang paling menyebabkan kekawatiran adalah sejak tahun 20132016, Australia telah memutuskan untuk menutup perbatasannya dari masuknya para pencari suaka dan pengungsi yang tidak memiliki dokumen administrasi resmi (BBC Indonesia 2016). Hal ini kemudian menyebabkan negara tersebut memiliki kebijakan untuk menempatkan sementara para pengungsi yang tertangkap di pulau tersendiri dan aparat negara menghalau masuknya imigran ilegal tersebut dengan mengirimkan kembali para pengungsi tersebut ke tengah lautan. Tindakan ini tentunya mengundang keprihatinan bersama karena adanya keputusan tersebut tidak hanya membahayakan para penumpang di kapal, melainkan juga menambah 'pekerjaan rumah' tambahan baru bagi pemerintah Indonesia karena para pengungsi tersebut memasuki wilayah perairan negara Indonesia. Kebijakan ini lebih lanjut juga dilakukan oleh Malaysia dalam merespon banyaknya arus 'manusia perahu' yang berasal dari Myanmar menuju Australia ketika terjadinya konflik Rohingnya di Negara Bagian Rakhine, Myanmar (BBC Indonesia 2016).

Berdasarkan berbagai fakta di atas membuktikan apabila perlu adanya lembaga yang dapat menyelesaikan permasalahan masuknya para imigran ilegal yang melewati dan memasuki perairan Indonesia. Selain itu, Indonesia belum memiliki panduan yang standar dalam menghadapi kasus seperti ini, mengingat Indonesia belum memiliki pengalaman yang panjang terkait arus pengungsi dan pencari suaka. Dalam hal ini, terutama jika terjadi arus 
pengungsi yang besar dalam saat tertentu yang bersamaan, tentunya Indonesia memerlukan pihak lain yang sudah cenderung lebih berpengalaman dan memiliki standar prosedur penanganan terhadap imigran ilegal secara lebih manusiawi.

\section{Kecelakaan dan Bencana Alam}

Indonesia sebagai negara tropis yang secara geografis berada diantara dua benua dan samudera yang besar menyebabkan negara ini sangat berpotensi terjadinya cuaca buruk dan iklim yang berbahaya. Adanya dua musim di Indonesia yang seiring dengan adanya pemanasan iklim global menyebabkan seringkali terjadinya cuaca yang tidak bersahabat dan cenderung membahayakan bagi arus transportasi laut dan udara yang melintasi perairan Indonesia. Disamping itu, juga terdapat kapal laut dan pesawat udara yang mengalami kerusakan mesin, kebakaran, hingga kehilangan kontak saat berada di wilayah laut Indonesia. Hal ini tentunya dapat menyebabkan kapal-kapal maupun pesawat yang ada di laut Indonesia dapat saja terbalik, terbakar, meledak, kandas, hingga tenggelam yang menyebabkan banyak korban jiwa (Noviani 2015).

Adanya perbedaan antara daratan dan lautan menyebabkan tantangan tersendiri yang dapat menyulitkan ketika melakukan evakuasi kapal dan para penumpang pasca terjadinya kecelakaan. Apabila penanganan tidak tepat, terlambat, atau tanpa adanya standar operasional maupun pengalaman yang cukup, maka akan dapat semakin menambah jumlah korban jiwa hingga tidak ditemukan korban jiwa, meskipun telah tercatat dalam catatan perjalanan berupa manifest pelayaran atau penerbangan. Bagi para keluarga korban penumpang dan awak kapal/pesawat hal ini justru akan semakin menambah beban psikologis dan bagi pemerintah sendiri dapat mengganggu citra penanganan kecelakaan di laut pada mata dunia.

Lebih lanjut, Indonesia sebagai salah satu negara yang berada dalam Ring of Fire dan dikelilingi oleh berbagai patahan di seluruh Indonesia, menyebabkan negara ini sangat rawan terhadap adanya bencana alam (Emaritim 2017). Adanya penanganan terhadap kebencanaan seharusnya menjadi prioritas utama, apalagi jika bencana yang terjadi berada di sekitar ataupun di lautan. Hal ini karena penduduk dan masyarakat yang mendiami Indonesia tersebar di berbagai pulau, sehingga ketika terjadi sebuah bencana alam dapat saja berdampak langsung terhadap kerusakan fasilitas maupun menimbulkan korban jiwa (Tribunnews 2017). Berdasarkan pada hal ini, pemerintah memerlukan adanya sebuah lembaga yang dapat menjadi pelaksana utama dalam penanganan bencana di perairan Indonesia, baik dalam evakuasi masyarakat, penyaluran bantuan, maupun perbaikan fasilitas bagi masyarakat yang berada di pulau-pulau Indonesia. 


\section{KONSEP KEAMANAN MARITIM}

Keamanan maritim awalnya dipahami sebagai upaya pengamanan dan pencegahan terhadap segala kegiatan di laut yang terkait dengan hal-hal ilegal ataupun kejahatan. Namun, seiring dengan kompleksitas permasalahan di laut, kemudian berkembang dengan kenyataan bahwa laut belum dapat dimanfaatkan secara maksimal, maka diperlukan adanya pengendalian dan pengaturan tata kelola kelembagaan yang baik di laut (Patria 2016). Lebih lanjut, ketika adanya permasalahan sengketa lautan yang mengikutsertakan adanya persenjataan dan politik maupun ekonomi menyebabkan lautan menjadi wilayah yang diperebutkan oleh banyak negara, terutama di Asia Tenggara.

Selanjutnya keamanan maritim ini kemudian tidak hanya terkait masalah kedaulatan nasional di laut, melainkan juga mencegah dan mengendalikan adanya berbagai tindakan yang terkait dengan kejahatan di seluruh perairan Indonesia, diantaranya: pembajakan di laut, penyelundupan narkotika, penjualan Sumber Daya Alam (SDA) ilegal, pencurian ikan dan biota laut, perdagangan manusia, masuknya teroris dan penjualan senjata, permasalahan arus pengungsi, hingga terkait dengan pertahanan perbatasan. Semua hal tersebut dilaksanakan dalam konsep keamanan maritim guna mendukung adanya kedaulatan negara, kebebasan pelayaran, keamanan dalam perdagangan, dan melestarikan lingkungan yang berada di lautan maupun sekitarnya.

Secara garis besar, keamanan maritim merupakan usaha dan bentuk kehadiran negara dalam menjaga dan mengatur segala aktivitas yang dilakukan di perairan dan lautan di seluruh Indonesia dapat berjalan dengan damai dan semestinya serta mencegah adanya berbagai kegiatan kejahatan yang dapat mengancam keamanan nasional dan dalam mengamankan kepentingan ekonomi maupun perdagangan nasional yang lebih besar (Viotti 1993).

\section{KERANGKA PEMIKIRAN KEPENTINGAN NASIONAL}

Kepentingan nasional dapat diartikan sebagai berbagai sasaran dan tujuan yang dilaksanakan oleh sebuah negara dalam upaya memajukan negara tersebut berdasarkan amanat konstitusi dan kebutuhan negara. Jika melihat kepentingan nasional dalam arti sempit, dapat dipahami sebagai usaha-usaha yang terkait dengan pendirian pangkalan militer, menjalin hubungan persahabatan dengan negara lain, dan melaksanakan kerjsama dengan negara atau aktor lain secara diplomatik (Clinton 1986). Sementara dalam kepentingan nasional yang lebih luas, kaitannya dengan Indonesia maka dapat dipahami jika kepentingan nasional negara ini adalah menjaga seluruh tumpah darah, memajukan kesejahteraan umum, dan ikut melaksanakan ketertiban dunia untuk mencapai sebuah negara yang yang merdeka, bersatu, berdaulat, adil dan makmur, sesuai Pembukaan Undang-Undang Dasar 1945.

Dalam memahami dan menjelaskan adanya kepentingan nasional sesuai amanat Konstitusi Indonesia, dapat difokuskan dalam berbagai bidang, diantaranya: kedaulatan, pertahanan dan keamanan, keutuhan wilayah, 
kemakmuran dan kesejahteraan, penegakan hukum dan keselamatan, dan tata kelola lembaga. Dalam kaitannya kelautan, maka diperlukan adanya pemahaman bagaimana mengelola laut Indonesia guna mencapai kemakmuran dan kesejahteraan bersama dengan mengelola dan mengamankan SDA yang ada di lautan agar tidak dikuasai oleh negara lain ataupun terjadi tindakantindakan yang dapat mengancam dan merugikan pihak-pihak tertentu utamanya terkait dengan kejahatan (Keliat 2009).

Berkaca pada hal tersebut, perlu adanya pendalaman fokus dalam hal kepentingan nasional kaitannya dengan maritim, yakni: meningkatkan pertahanan dan keamanan, penegakan hukum, maupun keselamatan di laut guna memecahkan berbagai permasalahan maritim di Indonesia. Hal tersebut sangat penting dalam upaya dan kehadiran negara dalam mempertahankan maupun meningkatkan kekuasaan negara, hingga pada akhirnya dapat mencapai keadilan sosial bagi seluruh rakyat Indonesia. Dalam hal ini, Pemerintah Indonesia dapat menjalin hubungan dan kerjasama dengan negara sahabat ataupun aktor internasional dalam upaya mencapai tujuan kepentingan nasional itu sendiri.

\section{METODE}

Dalam pengumpulan data dan penelitian ini, penulis menggunakan metode penelitian kualitatif dengan menggunakan data sekunder melalui berbagai sumber yang memiliki kaitan tentang kasus ini, antara lain: studi pustaka melalui literatur buku, jurnal, artikel, dan media massa. Data sekunder tersebut digunakan untuk mengetahui perkembangan terakhir melalui media massa daring maupun literatur lainnya yang juga membahas mengenai keamanan maritim dan kerjasama BAKAMLA RI-US Coast Guard yang dapat dibandingkan dan memperkaya tulisan penulis secara komprehensif. Pembahasan akan menggunakan metode deskriptif untuk memberikan pemahaman lebih mudah bagi pembaca.

\section{PEMBAHASAN}

\section{Poros Maritim Dunia}

Setelah terpilihnya Joko Widodo sebagai Presiden Republik Indonesia ke-7 pada tahun 2014, adanya penekanan terhadap Visi Nawa Cita atau Sembilan Cita-Cita sebagai program prioritas dalam melaksanakan pemerintahan guna mencapai Indonesia yang berdaulat secara politik, serta mandiri dalam bidang ekonomi dan berkepribadian dalam kebudayaan. Salah satu dari sembilan visi tersebut, yaitu: menghadirkan kembali negara untuk melindungi segenap bangsa dan memberikan rasa aman pada seluruh warga negara, melalui politik luar negeri bebas aktif, keamanan nasional yang terpercaya dan pembangunan pertahanan negara Tri Matra terpadu yang dilandasi kepentingan nasional dan memperkuat jati diri sebagai negara maritim (Presiden RI 2015).

Dalam mewujudkan visi pertama dalam Nawa Cita tersebut diterjemahkan dalam misi berupa adanya konsep Poros Maritim Dunia yang 
dideklarasikan oleh Presiden Joko Widodo pada Konferensi Tingkat Tinggi (KTT) ke-9 East Asia Summit (EAS) tanggal 13 November 2014 di Nay Pyi Taw, Myanmar (Kemenlu RI 2014). Terdapat lima pilar dalam Poros Maritim Dunia yang berkaitan erat dengan konsep keamanan maritim dan kepentingan nasional, antara lain:

1. Pembangunan kembali budaya maritim Indonesia.

2. Berkomitmen dalam menjaga dan mengelola sumber daya laut dengan fokus membangun kedaulatan pangan laut melalui pengembangan industri perikanan dengan menempatkan nelayan sebagai pilar utama.

3. Komitmen mendorong pengembangan infrastruktur dan konektivitas maritim dengan membangun tol laut, pelabuhan laut, logistik, dan industri perkapalan, serta pariwisata maritim.

4. Menerapkan diplomasi maritim, melalui usulan peningkatan kerja sama di bidang maritim dan upaya menangani sumber konflik, seperti pencurian ikan, pelanggaran kedaulatan, sengketa wilayah, perompakan, dan pencemaran laut dengan penekanan bahwa laut harus menyatukan berbagai bangsa dan negara dan bukan memisahkan.

5. Membangun kekuatan maritim sebagai bentuk tanggung jawab menjaga keselamatan pelayaran dan keamanan maritim.

Namun, dalam penelitian ini penulis cenderung berfokus pada dua pilar, yakni keempat dan kelima berupa diplomasi maritime dan membangun kekuatan maritim. Kedua pilar dalam Poros Maritim Dunia tersebut merupakan salah satu wujud nyata kehadiran negara dalam mengatur dan melindungi wilayah kelautan dengan memberikan perhatian yang lebih besar daripada era pemerintahan sebelumnya. Guna mewujudkan keamanan maritim dan melindungi kepentingan nasional maka kedua pilar tersebut harus dapat dilaksanakan agar Indonesia dapat menjadi sumbu atau kiblat dalam pengaturan maritim dunia yang memberikan keuntungan bagi semua pihak, utamanya rakyat Indonesia dan kepentingan ekonomi nasional.

Sebagai negara kepulauan terbesar di dunia, Indonesia memiliki berbagai potensi sekaligus tantangan yang harus dipecahkan guna mempercepat pembangunan dan mengantarkan negara Indonesia menjadi lebih maju. Di samping adanya letak geostrategis yang menguntungkan sekaligus dapat menimbulkan ancaman, maka perlu adanya kebijakan yang tidak hanya dapat menegakkan kedaulatan Indonesia, melainkan juga mewujudkan sebagai bangsa bahari yang sejahtera dan berwibawa dengan dapat mengelola dan melindungi kekayaan dari wilayah laut dan samudera yang ada untuk kepentingan rakyat sebesar-besarnya (Kemenhan RI 2015).

Dalam merealisasikan gagasan perlindungan keamanan maritim di wilayah Indonesia, maka dilakukan pendirian lembaga Badan Keamanan Laut Republik Indonesia (BAKAMLA RI) pada tahun 2014. Lembaga ini awalnya bernama Badan Koordinasi Keamanan Laut (BAKORKAMLA RI) sejak medio 2006, akan tetapi dirasa lembaga ini masih memiliki kekurangan dalam kewenangan dan tugasnya karena cenderung lebih menjadi badan koordinator, bukan menjadi garda terdepan yang melaksanakan pengamanan maritim (Prameswaran 2015). Hingga kemudian berganti menjadi BAKAMLA RI seiring 
dengan adanya Peraturan Presiden Nomor 178 Tahun 2014 tentang Badan Keamanan Laut (Prameswaran 2015). Secara garis besar, BAKAMLA RI memiliki tugas dan fungsi, antara lain: menyusun kebijakan nasional terkait keamanan laut, menyelenggarakan sistem peringatan dini, melakukan penjagaan dan patroli, memberikan bantuan teknis dan pencarian, dan hal-hal terkait pertahanan nasional. Berdasarkan hal tersebut, BAKAMLA berwenang untuk melakukan pengejaran, memeriksa dan menangkap pihak tertentu yang dicurigai, dan mengintegrasikan sistem keselamatan maupun keamanan laut Indonesia (Aziz 2016).

Keberadaan BAKAMLA RI yang memiliki 40 armada berbagai kapal, mulai kapal markas, patroli, maupun kapal kecil rata-rata melakukan penindakan 70 kapal ilegal yang diduga melakukan kejahatan di laut setiap tahunnya sejak 2017 (Hasan 2020). Hingga saat ini BAKAMLA RI memiliki berbagai kegiatan dan keberhasilan yang telah penulis ringkas, antara lain melakukan sinergi dengan TNI AL maupun lembaga yang menjaga wilayah laut Indonesia, tindakan penangkapan kapal ilegal asing maupun penyelundup dalam negeri, penghalauan kapal penjaga pantai Vietnam dan Tiongkok, evakuasi kecelakaan kapal maupun pesawat, operasi bersama dan kerjasama dengan lembaga penjaga keamanan laut lain baik di ASEAN maupun global, melaksanakan maupun menerima kunjungan dari pimpinan lembaga setingkat dari negara lain, menjadi anggota HACGAM maupun organisasi kerjasama lembaga penjaga laut internasional, dan melakukan edukasi kepada masyarakat Indonesia terkait pengamanan laut.

\section{Kerjasama BAKAMLA RI dan US Coast Guard}

Adanya Poros Maritim Dunia juga memberikan ruang bagi Indonesia untuk mengedepankan adanya diplomasi maritim guna menghilangkan sumber konflik di laut, seperti pencurian ikan, pelanggaran kedaulatan, sengketa wilayah, perompakan, dan pencemaran laut dengan menggandeng berbagai negara ataupun lembaga internasional untuk bekerjasama dan menjalin kemitraan. Sebagaimana diketahui bahwa adalah kebutuhan bersama untuk menjaga laut dunia sebagai sebuah kesatuan yang tidak dapat dipisahkan. Hal ini mengingat apabila sebuah permasalahan terjadi di sebuah wilayah perairan Indonesia, tidak hanya merugikan masyarakat setempat di sekitarnya melainkan juga dapat mengganggu kestabilan wilayah secara luas pada tingkat internasional. Berkaca pada hal tersebut diperlukan adanya kerjasama dan kemitraan bersama untuk saling menjaga keamanan dan kelestarian laut dunia.

Salah satu wujud nyata dalam kerjasama dan kemitraan bersama dalam menjaga kemaritiman dunia adalah dengan adanya nota kerjasama kelautan antara dua lembaga yang mewakili dua negara, yaitu: antara Indonesia dan Amerika Serikat melalui kerjasama BAKAMLA RI dan US Coast Guard (USGC). Sebagaimana diketahui, bahwa hubungan kerjasama bilateral antara Indonesia dengan Amerika telah dekat sejak lama meskipun terkadang mengalami masa-masa pasang dan surut. Guna memperkuat hubungan persahabatan kedua negara, maka dilakukan dengan adanya perjanjian hubungan bilateral dengan menitikberatkan pada kerjasama kemaritiman 
dalam mewujudkan kedaulatan dan menaati hukum internasional (Prameswaran 2015).

Kerjasama kedua badan kemaritiman ini terlaksana dan ditandatangani oleh kedua negara pada 24 Oktober 2015 yang dilaksanakan melalui Nota Kerjasama Maritim (Memorandum of Understanding on Maritime Cooperation) (Nusantara 2015). MoU tersebut tidak hanya sebagai bagian dari kemitraan strategis antara Indonesia dan Amerika Serikat, melainkan juga upaya untuk mencegah adanya berbagai aktivitas ilegal dan ancaman kelautan di wilayah perairan laut Indonesia. Kerjasama antara kedua badan kelautan ini menguntungkan Indonesia karena meningkatkan kapasitas dan pengalaman BAKAMLA RI, tidak hanya dalam hal Sumber Daya Manusia (SDM) melainkan juga transfer pengetahuan dan teknologi, kerjasama penanganan pencurian ikan dan kejahatan laut, dan prosedur penanganan evakuasi kecelakaan maupun kebencanaan. Kelanjutan dari kerjasama antara kedua lembaga tersebut kemudian dilaksanakan pertemuan Indonesia-United States Ocean Law and Maritime Policy Dialogue yang dilakukan setiap dua tahunan dimulai dari 2016. Agenda pertemuan dua tahunan ini dilaksanakan agar kedua negara memiliki pemahaman yang sama tentang konvensi hukum laut guna meminimalisir adanya kekeliruan di kedua negara (Nusantara 2015).

Beberapa tindak lanjut dari MoU lembaga penjaga kelautan kedua negara, diantaranya: dilaksanakannya dialog hukum laut dan kebijakan maritim pertama di Washington DC pada 2016 (Petro Energy 2016) dan kedua kalinya di Jakarta tahun 2018 (Maritim 2018); latihan bersama di Batam pada Agustus 2019 (Liputan 6 2019); melakukan pertukaran informasi, analisa informasi gabungan, Maritime Service Code, dan pelatihan bagi personil Bakamla di pusat pelatihan US Coast Guard di Amerika Serikat tahun 2020 (Ayo Jakarta 2020); dan pembentukan Maritime Security Training Center (MSTC) di Batam (CNN Indonesia 2020) maupun pelatihan Maritime Operational Threat Response (MOTR) pada 2021 (Radar Indonesia 2021).

\section{ANALISIS}

Penulis cenderung mendukung dan setuju dengan adanya kerjasama antara dua badan penjaga pantai Indonesia dan Amerika Serikat karena secara garis besar Indonesia dapat mengambil berbagai keuntungan yang dapat diadopsi oleh BAKAMLA RI dalam menjalankan tugasnya. Kerjasama antara BAKAMLA $\mathrm{RI}$ dan USGC meningkatkan kapasitas dan kualitas dari BAKAMLA RI dengan mempelajari berbagai tehnik, berbagi informasi dan pengalaman, membuat standar operasional, dan mendapatkan teknologi yang memudahkan BAKAMLA $\mathrm{RI}$ dalam menjaga keamanan laut Indonesia sebagaimana yang hendak diwujudkan dalam Poros Maritim Dunia, utamanya melakukan diplomasi maritim dan membangun kekuatan pertahanan maritim.

Berkaca pada implementasi kerjasama badan keamanan laut Indonesia dan Amerika Serikat dapat terlihat adanya peningkatan dan keberlanjutan pelatihan maupun pembentukan pusat pelatihan. Sebagai salah satu penjaga pantai tertua sejak 1915, USGC merupakan salah satu mitra penting bagi BAKAMLA RI yang baru berdiri tahun 2014. Tidak hanya dapat berbagi 
pengalaman, kerjasama dengan USGC mendapatkan banyak manfaat dan keuntungan bagi BAKAMLA RI, diantaranya mendapatkan pelatihan tehnik, pengadopsian standar keselamatan, peningkatan teknologi, menjadikan salah satu rujukan postur pertahanan maritim, mempelajari penanganan kemanusiaan ataupun kejahatan di laut, hingga berbagi informasi dan pembuatan pusat pelatihan MSTC. Selain itu, USGC merupakan salah satu institusi penjaga keamanan laut paling besar, ideal, dan berpengalaman di dunia mendukung bagi penguatan keamanan maritim Indonesia yang diwujudkan melalui berbagai kegiatan dan pusat pelatihan. Pendekatan dan standar yang digunakan oleh USGC sejak perang saudara di Amerika Serikat, Perang Dunia I hingga Perang Dingin terhadap persoalan pengungsian, kejahatan laut, bencana alam, kecelakaan, maupun saat konflik dapat menjadi keuntungan strategis secara diplomasi maritim maupun terhadap peningkatan kekuatan maritim oleh BAKAMLA RI.

Terbukti dalam pengamatan penulis sebagai institusi sipil yang melakukan pengamanan dan penegakan hukum di laut secara logo, tanda layanan, dan seragam BAKAMLA RI mengacu pada USGC. Selain itu, pengorganisasian, perencanaan, konsep, dan penggunaan armada juga merujuk USGC yang juga memiliki pusat komando, penggunaan helikopter, dan standar pelatihan penanggulangan kecelakaan hingga perompakan. Lebih lanjut, BAKAMLA RI juga menggunakan teknologi dalam pengawasan dan sistem peringatan dini sebagaimana yang digunakan oleh USGC. Meskipun secara bentuk perairan laut sedikit berbeda antara Indonesia dan Amerika Serikat, namun tehnik dan strategi yang digunakan kedua lembaga penjaga maritim ini cenderung serupa. Hal ini mengingat kedua negara sama-sama secara geografis memiliki letak daratan yang strategis, yakni Amerika Serikat berada diantara Samudera Pasifik dan Atlantik, sementara Indonesia berada diantara Samudera Hindia dan Pasifik. Adanya dialog bienial, latihan bersama, dan pembuatan pusat pelatihan dalam kerjasama dengan USGC terbukti mendukung profesionalitas BAKAMLA RI dalam menangani berbagai persoalan maritim di Indonesia yang menjadikan USGC sebagai mitra strategis BAKAMLA RI.

Setidaknya terdapat empat (4) keuntungan yang didapatkan oleh Indonesia dengan adanya kerjasama kedua lembaga maritim dari dua negara ini, diantaranya:

1. Memerangi Pencurian Ikan. Kerjasama antara Amerika Serikat dan Indonesia memungkinkan adanya peningkatan upaya Pemerintah Indonesia untuk memerangi dan mencegah pencurian ikan, tidak hanya di perairan Indonesia melainkan juga di kawasan ASEAN yang lebih luas. Tidak hanya melibatkan USGC, tetapi juga United States Agency for International Development / Badan Pembangunan Internasional AS (USAID), National Oceanic and Atmospheric Administration (NOAA), dan berbagai Departemen Pemerintah Amerika Serikat. Melalui kerjasama ini Indonesia akan mendapatkan bantuan teknologi, integrasi sistem keamanan dan keselamatan laut, pengembangan kapasitas Sumber Daya Manusia (SDM) BAKAMLA RI, pelatihan tentang Persetujuan Tentang Ketentuan Negara Pelabuhan Organisasi Pangan dan Pertanian 
(FAO Agreement on Port State Measures), penegakan hukum di bidang perikanan, dan analisis informasi intelijen. Adanya berbagai keuntungan di atas dapat meminimalisir adanya praktek pencurian ikan oleh BAKAMLA RI yang dilakukan nelayan asing ilegal yang selama ini mencari ikan di laut Indonesia, tetapi menjual hasil ikan tangkapan di negara asal mereka yang sangat merugikan nelayan dan rakyat Indonesia. Disamping pencurian ikan, adanya integrasi sistem yang dapat diadopsi dari teknologi Amerika Serikat guna meningkatkan keselamatan pelayaran di perairan Indonesia. Jika merujuk pada berbagai selat di Indonesia, antara lain: Selat Malaka, Selat Sunda, Selat Lombok, dan Selat Makassar cenderung sangat padat setiap harinya dilewati oleh ribuan kapal niaga dan penumpang. Hal tersebut tentunya jika tidak didukung oleh sistem keselamatan yang terintegrasi dapat menimbulkan adanya kecelakaan dan korban jiwa. Berkaca dari berbagai hal di atas guna mewujudkan Poros Maritim Dunia sebagai kepentingan nasional Indonesia, maka sangat penting apabila melalui BAKAMLA RI dapat meningkatkan keamanan laut dan keselamatan pelayaran agar yang dapat meningkatkan perekonomian Indonesia sekaligus melakukan diplomasi maritim dengan cara menjalin kerjasama berupa teknologi hingga pelatihan dengan Penjaga Pantai Amerika Serikat.

2. Memperluas Kerjasama IPTEK Bidang Kelautan. Berdasarkan kerjasama kelautan ini, Indonesia dapat melakukan observasi dan penelitian bersama terkait ekosistem laut, termasuk penelitian oseanografi serta keragaman perubahan iklim. Keuntungan ini akan meningkatkan pemahaman tentang interaksi kompleks antara laut dan atmosfer serta kemampuan untuk memprediksi respons perubahan iklim dan ekosistem jangka panjang. Adanya kerjasama IPTEK ini dapat memudahkan bagi BAKAMLA RI dalam memperkirakan curah hujan yang abnormal untuk wilayah tertentu di Indonesia dan memahami bagaimana fenomena oseanografi di Samudra Hindia dan Samudra Pasifik, hingga pada akhirnya dapat mencegah terjadinya kecelakaan di laut akibat cuaca buruk dan memudahkan ketika dilakukan evakuasi pasca adanya kecelakaan di wilayah perairan Indonesia. Selain itu, adanya kerjasama ini memungkinkan adanya pencegahan dan penanganan terhadap pencemaran laut yang diakibatkan oleh kelalaian pihak tertentu ataupun kecelakaan yang memerlukan adanya kesigapan agar tidak menghancurkan biota laut. Dalam kapasitas mewujudkan adanya kepentingan nasional melalui Poros Maritim Dunia sangat mendesak untuk adanya peningkatan kemampuan petugas BAKAMLA RI dalam kondisi oseanografi di seluruh laut dan samudra di seluruh Indonesia agar dapat mewujudkan adanya keamanan maritim dengan menjalin kerjasama dengan USGC.

3. Meningkatkan Keamanan Laut dan Pelabuhan. BAKAMLA RI dan U.S. Coast Guard melalui Program Export Control and Related Border Security Program dapat menyelenggarakan pelatihan bagi 
petugas penjaga pantai, tugas yang juga diemban oleh BAKAMLA RI. Selain itu, terdapat juga pelatihan Keamanan Pelabuhan Internasional dari USGC dalam melakukan peningkatan kapasitas untuk memenuhi standar Keamanan Kapal dan Pelabuhan Internasional (International Ship and Port Security) untuk mendeteksi serta mencegah ancaman keamanan di sektor transportasi laut. Seperti diketahui bahwa Badan Penjaga Pantai Amerika Serikat (U.S. Coast Guard) telah berdiri selama 103 tahun yang memiliki 243 kapal patroli ukuran sedang maupun besar, 1.650 kapal kecil, dan 201 pesawat yang menunjukkan bahwa lembaga tersebut telah sangat berpengalaman dan memiliki standar operasional yang handal karena telah lama melaksanakan tugas sebagai penjaga pantai. BAKAMLA RI dapat mengambil pengetahuan dan meniru standar operasional dalam pengamanan wilayah laut di Indonesia mengacu pada pengalaman yang dimiliki oleh USGC. Hal ini mengingat tantangan yang dimiliki oleh Indonesia juga serupa dengan yang selama ini terjadi di Amerika Serikat, yaitu: penyelundupan narkotika, perdagangan manusia, perompakan, dan penyelundupan persenjataan. Di samping itu, wilayah laut yang harus diawasi kedua negara juga relatif sama-sama besar, sehingga memberikan gambaran tugas dan tanggung jawab yang serupa. Dalam hal ini, penting bagi Indonesia dalam mengamankan wilayah laut dan pelabuhan dalam mencapai adanya keamanan maritim sebagai perwujudan dari Poros Maritim Dunia yang juga merupakan kepentingan domestik Indonesia yang salah satunya dapat terwujud dengan adanya kerjasama kedua badan penjaga pantai dari kedua negara.

\section{Membantu dan Melindungi Pergerakan Migrasi Tidak} Teratur. Dalam merespons adanya gelombang migrasi pengungsi menggunakan kapal menuju Australia yang melewati wilayah laut Indonesia pada medio 2013-2017 yang diduga berasal dari Afganistan, Myanmar, Sri Lanka, Iran, Irak, dan Bangladesh menyebabkan adanya penangana lebih lanjut. Hal ini diperlukan BAKAMLA RI guna membantu para pengungsi yang terdampar di wilayah Indonesia dengan menyediakan tempat penampungan sementara, memenuhi kebutuhan makanan, memberikan dukungan pelayanan kesehatan dan gizi, membantu jika para pencari suaka dan pengungsi tersebut secara sukarela ingin kembali ke negaranya, dan berbagi informasi agar dapat memberikan perlindungan secara internasional. BAKAMLA RI dapat berbagi pengalaman dan standar operasional dalam penanganan pengungsi secara kemanusiaan, namun tanpa mengurangi kewaspadaan terhadap perlindungan keamanan laut yang telah lama juga dilaksakan oleh USGC. Ini karena Amerika Serikat setiap tahunnya menjadi tujuan dari para pengungsi dan pencari suaka yang menginginkan adanya kehidupan yang lebih baik dari berbagai negara Asia, Pasifik, dan Amerika Latin dengan menuju ke negara tersebut melalui jalur laut, sementara USGC bertugas sebagai penjaga pantai di negara tersebut yang tentunya telah menjadi tugas sehari-hari. Merujuk 
pada fenomena arus imigran ilegal yang memasuki wilayah Indonesia dapat menjadi ancaman dari keamanan maritim Indonesia, namun jika dilihat dari sisi kemanusiaan maka perlu adanya penyelesaian yang lebih manusiawi. Diharapkan adanya kerjasama antara BAKAMLA RI dan USGC dapat memberikan penanganan pencari suaka dan pengungsi di perairan Indonesia sesuai dengan kaidah humaniter dengan tetap mengutamakan kewaspadaan dan pengawasan terhadap keamanan maritim sebagaimana yang ingin diwujudkan dalam Poros Maritim Dunia. Dalam membedah terlihat jelas bahwa kerjasama antara BAKAMLA RI dan USGC tidak hanya menguntungkan bagi kedua lembaga, namun lebih jauh merepresentasikan adanya kemitraan strategis antara Indonesia dan Amerika Serikat.

\section{KESIMPULAN}

Sebagai negara maritim dan kepulauan Indonesia memiliki kepentingan besar dalam mewujudkan adanya keamanan dan kestabilan laut di seluruh wilayah perairan Indonesia dalam upaya mewujudkan Poros Maritim Dunia. Penting bagi Indonesia untuk melaksanakan diplomasi maritim dan pembangunan kekuatan maritim. Adanya posisi geografis Indonesia yang strategis dan berada diantara dua benua maupun dua samudra menyebabkan Indonesia mendapatkan banyak keuntungan sekaligus tantangan.

Oleh karena itu, diperlukan adanya sebuah lembaga penjaga keamanan maritim yang kemudian bernama BAKAMLA RI dalam menjaga dan mengelola keamanan laut tidak hanya saat terjadi peristiwa melainkan pada tugasnya sehari-hari. Adanya kerjasama antara BAKAMLA RI dan USGC dapat meningkatkan adanya kapasitas dan kualitas dari BAKAMLA RI RI dengan didapatkannya berbagai tehnik, berbagi informasi dan pengalaman, membuat standar operasional, dan mendapatkan teknologi yang memudahkan BAKAMLA $\mathrm{RI}$ dalam menjaga keamanan laut Indonesia sebagaimana yang hendak diwujudkan dalam Poros Maritim Dunia.

\section{DAFTAR PUSTAKA}

Aziz, Abdul Nazili. 2016. "Kewenangan Badan Keamanan Laut (BAKAMLA) Dalam Pelaksanaan Pengamanan di Wilayah Perairan Indonesia". Diponegoro Law Journal. Vol. 5. No.4.

Ayo Jakarta. 2020. "Bakamla dan US Coast Guard Kembangkan Kerjasama Keamanan Maritim Lebih Luas". https://www.ayojakarta.com/read/2020/02/03/11516/bakamla-dan-uscoast-guard-kembangkan-kerjasama-keamanan-maritim-lebih-luas (Maret 18, 2021).

BBC Indonesia. 2016. "Aparat Australia kirim migran di tengah laut ke Indonesia".

https://www.bbc.com/indonesia/berita_indonesia/2016/03/160310_indone sia_migran_australia_ntt (November 18, 2020). 
BBC Indonesia. 2016. "UNHCR: Kebijakan Australia soal pengungsi tidak bisa diterima".

https://www.bbc.com/indonesia/dunia/2016/03/160323_dunia_pengungsi indonesia (November 18, 2020).

Berita Trans. 2017. "87 Aksi Bajak Laut Januari-Juni 2017, Didominasi Di Perairan Indonesia". http://beritatrans.com/2017/07/15/87-aksi-bajak-lautjanuari-juni-2017-didominasi-di-perairan-indonesia/ (November 17, 2020).

Clinton. W. David. 1986. "The National Interest: Normative Foundation". The Review of Politics. Vol 48.

CNN Indonesia. 2020. "Bakamla-AS Bangun Pusat Pelatihan Keamanan Maritim di Batam". https://www.cnnindonesia.com/nasional/20200203210559-20-

471323/bakamla-as-bangun-pusat-pelatihan-keamanan-maritim-di-batam (Maret 19, 2021).

Emaritim. 2017. "Bakamla Siapkan Kapal Patroli Bencana Erupsi Gunung Agung". $\quad$ http://www.emaritim.com/2017/10/ilustrasi-istimewa-baliemaritim.html (November 18, 2020).

Hasan, Syarief. 2020. "Penguatan Kelembagaan Sistem Keamanan Laut Indonesia". $\quad \mathrm{https} / / / \mathrm{kkp} . g o . i d / a n-c o m p o n e n t / m e d i a / u p l o a d-g a m b a r-$ pendukung/DitJaskel/publikasi-materi-2/sistem kelautan/PPT\%20Penguatan\%20Kelembagaan\%20Sistem\%20Keamana n\%20Laut\%20Indonesia.pdf (Maret 17, 2021).

Keliat. Makmur. 2009. "Keamanan Maritim dan Implikasinya bagi Indonesia". Jurnal IImu Sosial dan IImu Politik. Vol. 13. No. 01.

Kementerian Pertahanan Republik Indonesia. 2015. Buku Putih Pertahanan Indonesia Tahun 2015. Jakarta: Kemenhan RI.

Kemlu RI. 2014. "Presiden Jokowi Deklarasikan Indonesia Sebagai Poros Maritim Dunia". https://www.kemlu.go.id/id/berita/siaranpers/Pages/Presiden-Jokowi-Deklarasikan-Indonesia-Sebagai-PorosMaritim-Dunia.aspx (November 17, 2020).

Liputan 6. 2019. "Perdana, Bakamla RI dan US Coast Guard Gelar Latihan Bersama". https://www.liputan6.com/global/read/4037542/perdanabakamla-ri-dan-us-coast-guard-gelar-latihan-bersama (Maret 17, 2021).

Maritim. 2019. "Indonesia dan Amerika Serikat Pererat Kerja Sama Kemaritiman". https://maritim.go.id/indonesia-dan-amerika-serikatpererat-kerja-sama-kemaritiman/ (Maret 17, 2021).

Noviani, Ana 2015. Januari-Mei 2015, "Bakamla: Terjadi 135 Kecelakaan Kapal". http://kabar24.bisnis.com/read/20150601/186/439272/januarimei-2015-bakamla-terjadi-135-kecelakaan-kapal (November 20, 2020).

Nusantara Maritime News. 2015. "Indonesia dan AS Tandatangani MoU Kerjasama Sektor Maritim". https://maritimenews.id/10/kzxkjnvLx/ (November 18, 2020).

Parameswaran, Prashant. 2015. "Exclusive: US, Indonesia Eye New Defense Pacts For Jokowi Visit". https://thediplomat.com/2015/10/exclusive-usindonesia-to-sign-new-defense-pacts-during-jokowi-visit/ (November 17, 2020). 
Parameswaran, Prashant. 2015. "Indonesia's Maritime Ambition: Can Jokowi Realise It?". https://www.rsis.edu.sg/rsis-publication/rsis/co15044indonesias-maritime-ambition-can-jokowi-realise-it/\#.W8RSGBMzYWq (November 20, 2020).

Parameswaran, Prashant. 2015. "What's Behind the Missing US-Indonesia Maritime Security Pact?". https://thediplomat.com/2015/11/whats-behindthe-missing-us-indonesia-maritime-security-pact/ (November 18, 2020).

Patria, Arie Utama. 2016. Konsep Keamanan Maritim di Indonesia. Jakarta: Universitas Pertahanan.

Petro Energy. 2016. "Indonesia - AS Gelar 1st Indonesia-United States Maritime Law and Ocean Policy Dialogue". https://petroenergy.id/article/indonesia--as-gelar-1st-indonesia-unitedstates-maritime-law-and-ocean-policy-dialogue?c=maritime (Maret 16, 2021).

Presiden RI. 2015. "Indonesia Sebagai Poros Maritim Dunia". http://presidenri.go.id/berita-aktual/indonesia-sebagai-poros-maritimdunia.html (November 20, 2020).

Radar Indonesia. 2021. "Kepala Bakamla RI Terima Kunjungan Kedubes Amerika Serikat". http://www.radarindonesia.com/2021/01/kepalabakamla-ri-terima-kunjungan_15.html (Maret 17, 2021).

Tribunnews Batam. 2017. "Laka Laut - Bakamla Kerahkan KN Belut Laut untuk Bantu Cari Korban Tanker Tabrakan". http://batam.tribunnews.com/2017/09/13/laka-laut-bakamla-kerahkan-knbelut-laut-untuk-bantu-cari-korban-tanker-tabrakan (November 17, 2020).

Viotti. Paul \& Kauppi. Mark. 1993. International Relations Theory: Realism, Pluralism, Globalism. New York: Macmillan. 